\title{
Rectal mucosa in cows' milk allergy
}

\author{
N IYNGKARAN,${ }^{*}$ M YADAV $\dagger$ AND C G BOEY $\ddagger$ \\ Departments of *Paediatrics and $\ddagger$ Pathology, University Hospital, and $†$ Department of Genetics and Cellular \\ Biology, University of Malaya, Kuala Lumpur
}

SUMMARY Eleven infants who were suspected clinically of having cows' milk protein sensitive enteropathy were fed with a protein hydrolysate formula for six to eight weeks, after which they had jejunal and rectal biopsies taken before and 24 hours after challenge with cows' milk protein. When challenged six infants (group 1) developed clinical symptoms and five did not (group 2). In group 1 the lesions developed in both the jejunal mucosa (four infants at 24 hours and one at three days), and the rectal mucosa, and the injury was associated with depletion of alkaline phosphatase activity. Infants in group 2 were normal. It seems that rectal injury that develops as a direct consequence of oral challenge with the protein in reactive infants may be used as one of the measurements to confirm the diagnosis of cows' milk protein sensitive enteropathy. Moreover, ingestion of such food proteins may injure the distal colonic mucosa without affecting the proximal small gut in some infants.

Injury to the mucosa of the proximal small bowel is a characteristic feature of food protein sensitive gastrointestinal allergy. ${ }^{1-3}$ The pathogenesis and the appearance of clinical symptoms depends on several interdependent factors including the integrity of the immunodigestive barriers that modulate the movement of macromolecules across the gut, ${ }^{4}$ the severity and extent of villous damage caused by the protein, 5 the types of immune responses triggered by the protein, ${ }^{6-10}$ the presence of enteric infections ${ }^{11}$ and others. ${ }^{4}{ }^{12}$ At present it is not known whether the whole gut is potentially sensitive to the offending food protein in a reactive infant. In a retrospective study of 53 patients aged 15 days to 17 years suspected of gastrointestinal allergy, Goldman and Proujansky noted that they could separate their series of cases into two groups with the principal effects in the rectum and colon on the one hand, and in the small bowel mucosa on the other. ${ }^{13}$ In their study only 10 patients were biopsied at both sites, and it is not clear whether these infants had food protein intolerance because in some the exclusion diet brought no relief. We have previously noted development of mucosal lesions in both the proximal jejunum and the distal colon in a single infant with cows' milk protein sensitive enteropathy challenged with oral cows' milk protein. ${ }^{5}$ This observation suggested that oral challenge with the protein may evoke morphological changes not only in the jejunum but also in the rectum in infants sensitive to food proteins.

The present study was undertaken to obtain further data on changes in the rectal mucosa and changes in the proximal jejunal mucosa in infants who were allergic to milk.

\section{Patients and methods}

Eleven infants (six boys and five girls) who presented with diarrhoeal disease were studied. Eight of them had had diarrhoea for more than seven days and three had recurrent bouts of diarrhoea over a six week period with poor weight gain before admission. After correction of fluid and electrolyte imbalances, ${ }^{14}{ }^{15}$ the infants were given a lactose free cows' milk formula (AL 110, Nestlé) but these infants failed to improve after 48 hours. Moreover, only four of them had pathogens in their stools. Thus it was suspected clinically that the diarrhoeal disease was caused by intolerance to cows' milk protein and so the infants were first given a formula free of cows' milk protein-such as Pregestimil (Mead Johnson), Nutramigen (Mead Johnson), or Alfare (Nestlé) - and then further tests were carried out. ${ }^{16}$ All infants were kept in hospital until the stools were normal, they were feeding well, and gaining weight. They were then discharged home. The mothers were supplied with the appropriate 
formulas and instructed not to offer any other milk without consulting us. Six weeks later the infants were readmitted for further study.

\section{COWS' MILK PROTEIN CHALLENGE TEST}

The infants were diagnosed as having cows' milk protein sensitive enteropathy on the criteria outlined previously based on cows' milk protein challenge studies. ${ }^{13}$ In brief, the test consisted of an initial feed of $5 \mathrm{ml}$ of a low lactose cows' milk formula (AL 110, Nestlé). If no reaction occurred the volume was doubled hourly for the first four hours, and subsequently every three hours, until daily requirements were met. If the infants developed severe symptoms the challenge was terminated and the infant placed on an oral rehydrating solution and then a protein hydrolysate formula.

\section{JEJUNAL BIOPSY AND RECTAL BIOPSY}

Jejunal and rectal biopsies were carried out after informed consent was obtained from the parents. Biopsy specimen were taken before challenge and then again 20-24 hours after the introduction of the provocation formula, irrespective of the development of symptoms. The proximal jejunal biopsy specimen was taken through the mouth with the Watson paediatric capsule placed at, or just distal to, the duodenal-jejunal flexure. The specimen was then examined under a dissecting microscope. A portion of the specimen was sent for histological examination, and the remainder for enzyme assay or other studies.

Appearances of the jejunal biopsy specimen were classified according to: (i) villous morphological appearance under the dissecting microscope, (ii) villus:crypt height ratio, (iii) epithelial cells, and (iv) the degree of cellular infiltration. The morphological changes in the mucosa were scored by our modification $^{93}$ of the method of Townley et al. ${ }^{17}$

The rectal biopsy specimen was taken with a Watson paediatric capsule $7-10 \mathrm{~cm}$ from the anus. A portion of the tissue was sent for histological examination and the remainder for enzyme assay. The main histological features noted were (i) morphological changes, necrosis, and degeneration of the epithelial cells; (ii) the degree of inflammatory infiltration of the epithelial layer; (iii) the density of the inflammatory cells within the lamina propria; and (iv) signs of degeneration and necrosis in the crypts and glandular cells.

\section{ASSAY FOR ALKALINE PHOSPHATASE}

Biopsy specimens, frozen at $-20^{\circ} \mathrm{C}$ for no longer than two weeks, were used for the assay. Alkaline phosphatase and protein estimation on the tissue were carried out as described previously. ${ }^{18}$
OTHER INVESTIGATIONS

Attempts were made to isolate parasitic, bacterial, and viral pathogens from the stools by culture, and by light and electron microscopy. In addition, a mucosal imprint was taken routinely to detect Giardia lamblia by the method of Kamath and Murugasu. ${ }^{19}$ Testing of stools by the Clinitest method ${ }^{20}$ to detect secondary sugar intolerance was carried out at initial illness and after cows' milk protein challenge if diarrhoea occurred.

\section{STATISTICAL ANALYSIS}

The changes in the alkaline phosphatase activities (IU/g protein) between the two sets of biopsy specimens of the jejunal and rectal mucosa were analysed by the paired Student's $t$ test corrected for small sample size.

\section{Results}

Two Malay infants, four Chinese, and five Indians were studied. One infant was breast fed for a month, two had had bottle and breast feeds for a month, and the remaining eight had been bottle fed from birth.

At admission all 11 infants had diarrhoea, and other symptoms included vomiting $(n=4)$, fever $(n=4)$, anal excoriation $(n=8)$, and abdominal distension $(n=1)$. Sugar intolerance (positive Clinitest) was present in all the infants.

Salmonella spp and Escherichia coli were each isolated from the stools of one infant, and rotavirus from two infants. The stools from the remaining infants did not grow any bacterial, viral (rotavirus), or parasitic enteric pathogens. The clinical features of the infants are summarised in table 1 .

At readmission, after a six to eight week period of receiving a protein hydrolysate formula, all the infants were clinically well and had gained weight satisfactorily. In none did the stools grow any enteric pathogens.

\section{CHALLENGE STUDIES}

On the basis of the clinical response to challenge with cows' milk protein the infants were divided into two groups.

Group 1 comprised six infants who developed symptoms of diarrhoea, vomiting, fever, lethargy,

Table 1 Clinical features in 11 infants with diarrhoea. Figures are expressed as median (range).

\begin{tabular}{lc}
\hline Age at admission (days) & $120(21-510)$ \\
Age at onset of diarrhoea (days) & $113(14-495)$ \\
Duration of diarrhoea (days) & $7(2-21)$ \\
\hline
\end{tabular}


and weight loss. The symptoms occurred between two and 24 hours in four, and two to 14 days in the other two. In four of these six infants the jejunal mucosa after challenge had demonstrable morphological changes associated with significant $(p<0 \cdot 01)$ depletion of the mucosal alkaline phosphatase activities (table 2). Two infants, however, one with symptoms at 48 hours and the other after 14 days, did not show morphological changes in the jejunal mucosa 24 hours after the challenge. Interestingly, in one of these two infants the mucosal alkaline phosphatase activity after challenge was considerably increased over that before the challenge. A repeat biopsy in the latter infant, however, three days after the challenge (while still on cows' milk) and 24 hours after clinical symptoms had appeared, showed severe morphological changes in the jejunal mucosa; these were also associated with severe depletion of the mucosal alkaline phosphatase activity. A repeat biopsy in the other infant was not done. The rectal mucosa after challenge in all six infants had severe morphological changes associated with significant

Table 2 Changes in the histological condition and alkaline phosphatase content of jejunal and rectal mucosa in six infants who reacted to challenge with cows' milk protein (group 1)

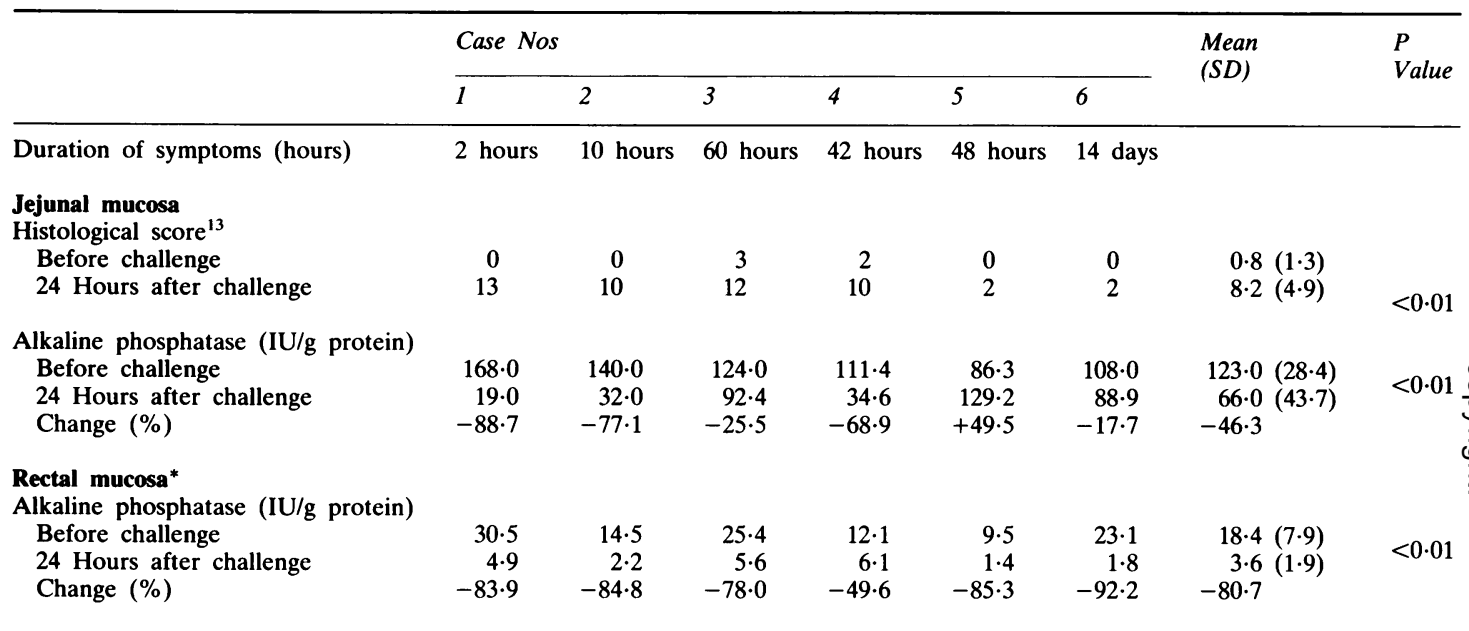

${ }^{*}$ Histological appearances in all cases were normal before challenge and showed evidence of damage after challenge.

Table 3 Changes in the histological condition and alkaline phosphatase content of jejunal and rectal mucosa in five infants who did not react to challenge with cows' milk protein (group 2)

\begin{tabular}{|c|c|c|c|c|c|c|c|}
\hline & \multicolumn{5}{|c|}{ Case Nos } & \multirow{2}{*}{$\begin{array}{l}\text { Mean } \\
(S D)\end{array}$} & \multirow{2}{*}{$\begin{array}{l}P \\
\text { Value }\end{array}$} \\
\hline & 1 & 2 & 3 & 4 & 5 & & \\
\hline \multicolumn{8}{|l|}{ Jejunal mucosa } \\
\hline \multicolumn{8}{|l|}{ Histological score ${ }^{13}$} \\
\hline Before challenge & 3 & 2 & 2 & 0 & 0 & $1.4(1 \cdot 3)$ & \multirow{2}{*}{$>0.05$} \\
\hline 24 Hours after challenge & 3 & 3 & 4 & 2 & 2 & $2 \cdot 8(0 \cdot 7)$ & \\
\hline \multicolumn{8}{|c|}{ Alkaline phosphatase (IU/g protein) } \\
\hline Before challenge & $52 \cdot 1$ & $88 \cdot 6$ & $45 \cdot 9$ & $167 \cdot 5$ & $120 \cdot 0$ & $94.8(45 \cdot 8)$ & \multirow{3}{*}{$0 \cdot 8$} \\
\hline 24 Hours after challenge & $178 \cdot 7$ & $78 \cdot 5$ & $201 \cdot 5$ & $145 \cdot 2$ & $128 \cdot 0$ & $146.4(47.5)$ & \\
\hline Change $(\%)$ & $+243 \cdot 0$ & $-11 \cdot 4$ & $+339 \cdot 8$ & $-13 \cdot 3$ & $+6 \cdot 7$ & $+54 \cdot 4$ & \\
\hline \multicolumn{8}{|c|}{ Rectal mucosa* } \\
\hline \multicolumn{8}{|c|}{ Alkaline phosphatase (IU/g protein) } \\
\hline Before challenge & 4.9 & $15 \cdot 0$ & $3 \cdot 7$ & $12 \cdot 6$ & $8 \cdot 4$ & $8.9(4.8)$ & \multirow{3}{*}{$0 \cdot 6$} \\
\hline 24 Hours after challenge & $13 \cdot 6$ & $22 \cdot 0$ & $4 \cdot 2$ & $8 \cdot 3$ & $7 \cdot 0$ & $11.0(7 \cdot 0)$ & \\
\hline Change $(\%)$ & $+177 \cdot 6$ & $+46 \cdot 7$ & $+13 \cdot 5$ & $-34 \cdot 1$ & $-16 \cdot 7$ & +23.6 & \\
\hline
\end{tabular}

${ }^{*}$ Histological appearances were normal both before and after challenge. 
$(\mathrm{p}<0.01)$ depletion in mucosal alkaline phosphatase activities.

Five of the six reactive infants (early and delayed) required hypoallergenic milk substitutes to recover. The sixth infant (case 5, table 2) had diarrhoea with perianal excoriation for three days but improved spontaneously despite continued feeding with cows' milk protein. He was not available for further biopsy studies.

Group 2 comprised five infants who did not react to the challenge with cows' milk protein. The rectal mucosa in these infants showed no change. The alkaline phosphatase activities after challenge were increased in the jejunal biopsy specimen in two infants, and in the rectal biopsy specimen in three infants (table 3 ).

HISTOLOGICAL FEATURES OF RECTAL BIOPSY SPECIMENS The architecture of the rectal mucosa before challenge with cows' milk was normal and there was no evidence of crypt branching, atrophy, or dense inflammatory cell infiltration of the lamina propria.

The rectal mucosa after challenge in the six infants who reacted to the cows' milk protein showed several abnormal features: cuboidal metaplasia with loss of polarity of the nuclei of the epithelial cells; increased infiltration of the epithelium with lymphocytes; necrosis of the surface epithelial cells; infiltration of the lamina propria with inflammatory cells (lymphocytes, plasma cells, monocytes, and eosinophils); necrosis of the crypts and glandular cells; and variable degrees of mucin depletion in the glandular cells.

\section{Discussion}

Our criteria for the diagnosis of cows' milk protein sensitive enteropathy are based on the morphological changes of the jejunal mucosa and development of clinical symptoms within 24 hours of challenge with cows' milk protein. ${ }^{11}$ Using these criteria only four of the 11 infants in the present series were diagnosed as having cows' milk protein sensitive enteropathy; the other seven infants were considered not to have it. In two of the latter seven infants, however, though the oral challenge induced no jejunal abnormality, symptoms appeared two to 14 days after challenge with cows' milk protein. These two infants with delayed reactions would not have been classified as having cows' milk protein sensitive enteropathy by our criteria because the jejunal biopsy was unchanged 24 hours after challenge with cows' milk protein. In one of the two infants, a follow up biopsy obtained three days after the challenge, indicated mucosal injury, but the other infant was not subsequently biopsied. Never- theless an interesting feature of all the reactive infants, both early and delayed, was the development of rectal mucosal lesions associated with depletion of mucosal alkaline phosphatase activity.

The rectal mucosal abnormality appeared within 24 hours of initiating the oral milk challenge, which strongly suggests that the cows' milk proteins were directly responsible for the response. In some the rectal changes may have been caused by the diarrhoea, which could have brought toxic products from the upper gut to the colon and rectum, but in two cases this was not so because colonic changes occurred in the absence of jejunal changes. Moreover, none of the five unreactive infants had similiar lesions in the rectal mucosa. These observations suggest that the ingested food proteins could cause damage to the distal colon independently of the proximal small gut. The pathogenetic mechanisms responsible for the rectal mucosal injury remain unclear, but the increased infiltration with mononuclear cells and eosinophils suggests an immune associated injury. Although colitis and proctitis specifically induced by milk proteins are well known in children, ${ }^{21-24}$ their association with gastroenteritis remains uncertain.

The severe proctitis in the two infants who did not have any injury to the proximal jejunum is an unexpected but interesting finding. In both the infants symptoms were delayed. Goldman and Proujansky in their study of 53 infants with allergic gastroenteropathy observed that of 15 cases of allergic proctitis, all but one had lesions limited to the rectum and colon. ${ }^{13}$ These, together with our present observations, are contrary to previous reports in which severity of mucosal damage caused by gluten or cows' milk protein, were noted to decrease in severity craniocaudally. We noted that mucosal disaccharidases and alkaline phosphatase activities were depleted in both the proximal and distal jejunal biopsy specimen after challenge with cows' milk but the enzyme depletion was greater in the proximal than in the distal biopsy specimens. ${ }^{5}$ This craniocaudal decrease in severity of mucosal damage was more obvious in reactive infants who had only mucosal injury compared with reactive infants who had both mucosal injury and symptoms. In the latter group the mucosal response was more widespread, and in one case lesions were also noted in the rectal mucosa.

Grybowski has shown that the rectal mucosa was damaged and there were clinical features of enterocolitis in eight infants sensitive to cows' milk protein. ${ }^{22}$ Taken together it appears that the entire gut is potentially sensitive to cows' milk protein in cows' milk protein sensitive enteropathy. The extent and severity of damage to the mucosa after chal- 
lenge with cows' milk protein in reactive infants depend on several opposing sets of factors, with competency of the immunodigestive system and other protective barriers of the mucosa on one side, and the quantity and immunogenecity of cows' milk protein and other adverse factors (such as enteric infection and age of infant) on the other. Thus the clinical and pathogenetic responses may be part of a broad range of reactions in which the site, nature, severity, and extent of damage will depend on the spread of the protein and the nature of the infant's immune response.

In clincial practice the management of infants with chronic diarrhoea requires the need to establish whether the illness is caused by intolerance of food protein. Although jejunal biopsy through the mouth has been the preferred method of diagnosis, it has the disadvantage of requiring expensive equipment and skilful intubation. By contrast, rectal biopsy may be obtained quickly with little equipment and could be the alternative option when jejunal biopsy is not possible. This study shows that the changes in rectal mucosa before and after challenge with oral cows' milk protein predicted intolerance to cows' milk in the infants studied.

The project was partly funded by CHILD (Child Information, Learning and Development Centre) Malaysia, and Dumex Malaysia. Some facilities were provided by the Institute of Advanced Studies.

\section{References}

${ }^{1}$ Iyngkaran N, Robinson MJ, Prathap K, Sumithran E, Yadav M. Cows' milk protein-sensitive enteropathy: combined clinical and histological criteria for diagnosis. Arch Dis Child 1978;53: $20-6$.

2 Iyngkaran N, Abidin Z, Meng LL, Yadav M. Egg-protein induced villous atrophy. J Pediatr Gastroenterol Nutr 1982;1: 29-34.

3 Iyngkaran N, Yadav M, Looi LM, Boey CG, Lam KL, Balabaskaran S, Puthucheary SD. Effect of soy protein on the small bowel mucosa of young infants recovering from acute gastroenteritis. J Pediatr Gastroenterol Nutr 1988;7:68-75.

4 Walker WA, Isselbacher KJ. Uptake and transport of macromolecules by the intestine. Possible role in clinical disorders. Gastroneterology 1974;67:531-50.

5 Iyngkaran N, Yadav M, Boey CG, Lam KL. Severity and extent of upper small bowel mucosal damage in cows' milk proteinsensitive enteropathy. J Pediatr Gastroenterol Nutr 1988;7: 667-74.
${ }^{6}$ Stokes CR, Soothill JF, Turner MW. Immune exclusion is a function of IgA. Nature 1975;255:765-6.

7 Walker WA, Isselbacher KJ. Intestinal antibodies. $N$ Engl $J$ Med 1977;267:767-9.

8 Yadav M, Iyngkaran N. Immunological studies in cows' milk protein-sensitive enteropathy. Arch Dis Child 1981;56:24-30.

9 Carini C. IgE immune complexes in food allergy: significance, pathogenicity and clinical considerations. Clin Allergy 1987;17: 485-97.

${ }^{10}$ Ferguson A, McClure JP, Townley RRW. Intraepithelial lymphocyte counts in small intestinal biopsies from children with diarrhoea. Acta Paediatr Scand 1976;65:541-7.

11 Kumate J, Isibasi A. Pediatric diarrhoeal diseases: a global perspective. Pediatr Infect Dis 1986;5:521-8.

12 Iyngkaran N, Yadav M. Food alltergy In: Marsh MN, ed. Immunopathology of small intestine. Chichester: John Wiley, 1987:415-49.

${ }^{13}$ Goldman H, Proujansky R. Allergic proctitis and gastroenteritis in children. Clinical and mucosal biopsy features in 53 cases. $\mathrm{Am}$ J Surg Pathol 1986;10:75-86.

14 Iyngkaran N, Zainal A, Lam SK, Puthucheary SD. Acute gastroenteritis in Malaysian children aetiological and therapeutic considerations. Med J Malaysia 1980;34:403-8.

15 Zainal A, Iyngkaran N, Geethan R. Oral rehydration in infantile diarrhoea. The optimum carbohydrate-electrolyte composition. J Singapore Paediatr Soc 1980;20:100-3.

16 Iyngkaran N, Zainal A, Robinson MJ, Yadav M, Boey CG, Chai KH. Nutritional rehabilitation of infants with protracted diarrhoea: comparative study of three therapeutic regimen. Asean Journal of Clinical Science 1982;3:160-6.

17 Townley RRW, Khaw KT, Shwachman H. Quantitative assay of dissacharidase activities of small intestinal mucosal biopsy specimens in infancy and childhood. Pediatrics 1965;36:911-21.

18 Iyngkaran N, Yadav M, Balabaskaran S, Sumithran E. In vitro diagnosis of cows' milk protein sensitive enteropathy by organ culture method. Gut 1981;22:199-202.

19 Kamath KR, Murugasu R. A comparative study of four methods for detecting Giardia lamblia in children with diarrhoeal disease and malabsorption. Gastroenterology 1974;66:16-21.

${ }^{20}$ Kerry ER, Anderson CM. A ward test for sugar in the faeces. Lancet 1964;i:981.

21 Ament M, Rubin CE. Soy protein-another cause of the flat intestinal lesion. Gastroenterology 1972;62:227-34.

22 Grybowski JD. Gastrointestinal milk allergy in infants. Pediatrics 1967;40:354-60.

23 Jenkins HR, Pincott JR, Soothill JF, Milla PJ, Harrier JJ. Food allergy: the major cause of infantile colitis. Arch Dis Child 1984;59:326-9.

${ }^{24}$ Klein NC, Hargrove RL, Sleisenger MH, Jeffries GH. Eosinophilic gastroenteritis. Medicine 1970;49:229-319.

Correspondence to Dr N Iyngkaran, Department of Paediatrics, University Hospital, 59100 Kuala Lumpur, Malaysia.

Accepted 11 April 1989 